\title{
Legitimate Generators of Knowledge: Developing Teacher and Teacher Educator Identity through Participation in Collaborative Undergraduate Research
}

\author{
Sherry Dismuke \\ https://orcid.org/0000-0003-1676-7081
}

Lisa Beymer

https://orcid.org/0000-0001-6194-445X

Julianne Mori

https://orcid.org/0000-0002-9377-7307

\section{Claire Oberg \\ https://orcid.org/0000-0003-1030-5791}

\author{
A.J. Zenkert \\ https://orcid.org/0000-0003-1995-990
}

\section{Abstract}

To counteract the notion that teachers are not researchers, three clinical faculty members working in a public university in the United States joined with two undergraduate teacher education candidates to participate in a phenomenological collaborative self-study to examine how our different lived experiences within collaborative undergraduate research informed our researcher identities as teacher educators and as developing teachers. Data sources included: researcher journals, written responses to mirrored prompts, meeting notes and transcriptions of critical friend conversations. Data was analysed using cyclical coding across all data sources. The article highlights collective inquiry spaces sites as safe spaces for both teacher educators and 
undergraduate candidates to co-construct researcher identities; f. Furthermore, developing efficacy as researchers brought undergraduate communities out of the shadows to create a sustainable socially cohesive community of practice around research.

Keywords: collaborative self-study, critical friends, preservice teacher education, teacher educator identity, teacher identity, undergraduate research,

\section{Introduction}

Hamilton (2005) reminds us that the traditional view of teaching has long held that teachers are not researchers and that some feel the role of knowledge generation lies outside the identity of teaching. This is also true for teacher educators. Rice et al. (2015) cite Luna et al.'s (2004:69) work that uncovered teacher educators' 'painful feelings of being imposters in academia'. These feelings are rooted in traditional assumptions that teachers are 'passive recipients of others' expert knowledge rather than knowers in (their) own right' (Luna et al. 2004:69). These views have a profound impact on teachers and teacher educators' views of themselves as researchers and their capacity and potential to use their practical and conceptual knowledge of teaching to generate knowledge for the field of teaching. These traditional assumptions about the role of teachers can be an impediment to the development of teachers and teacher educators as researchers.

\section{Barriers to Developing Research Identity}

Teacher educators often make the transition from classroom teacher or school administrator to a university faculty member with little to no training (Goodwin \& Kosnick 2013). It is a steep uphill climb to develop the competencies necessary to negotiate the multiple roles of a teacher educator successfully: university teaching, research and clinical supervision across hybrid spaces within the university and in p-12 school buildings (Martin et al. 2011). Murray and Male (2005) found that it can take three years for new teacher educators that came out of the classroom to establish their identities as researchers. It is not surprising then that the transition from an identity of classroom teacher to an identity as researcher is often associated with 
feelings of self-doubt and vulnerability (Kirk \& Lipscombe 2019). While universities may have research support groups for new faculty members, teacher educators may still see themselves as outsiders in these groups. These self-perceptions of identify are influenced by the ways classroom teachers and their roles have been defined and named by the public and systems in which they work.

Hamilton and Pinnegar (2015) document that this self-doubt is further compounded by the ways in which teachers and teacher educators have been 'named' by others. Government policies and society's perceptions of teachers influence the ways in which teachers define themselves and the roles they play. For example, the implementation of scripted curriculum at some schools implies that curriculum is better constructed by experts rather than teachers themselves and many alternative certification programmes suggest that anyone can be 'trained' to teach. In higher education this perception continues; in academia, schools that prepare teachers can be considered professional programmes, rather than academic fields of study. Gee (2000: 102) explains that one part of identity formation is institutional identity. Often teacher educators have formed their professional identities based on society's views of what a classroom teacher is or should do. Job descriptions for teachers traditionally do not include or describe duties related to research or teacher inquiry. As classroom teachers move into university roles, their own professional identities are not in alignment with the institutional identity of a professor. Bullock and Ritter (2011) found that moving from a classroom teacher to an academic requires reconstructing a professional identity that conforms to institutional demands.

This struggle to develop researcher identity is further compounded by institutional hierarchical structures and positionality inherent in university structures and traditions. While teaching is the fundamental backbone of universities, research and the development of new knowledge ares at the centre of a university's reputation and therefore a faculty with high research productivity is highly valued ( $\mathrm{Ng} \&$ Pemberton 2013). This is a complete change in institutional identity for a teacher educator who comes into academia from an institutional culture that values teaching and learning above all else. At research-intensive universities, Dinkelman (2011) questions how many education faculty members would actually claim the title of teacher educator. He proposed that within the university hierarchy, the closer one identifies publicly with the practice of teacher education, the lower one's 
status as a researcher. These perceptions of teachers and teacher educators as practitioners, as opposed to intellectuals, disrupt the identity development of teachers and teacher educators as generators of new knowledge. These barriers, however, do not just exist in higher education but begin in teacher preparation programmes and transfer into classroom teaching.

Northfield (1993; 1994a; 1994b), a teacher-researcher-scholar, maintained the value of teachers contributing to our general knowledge of teaching. Hamilton (2005) provides a review of Northfield's work in Australia on the teacher as researcher over his career. Northfield believes that teachers should develop as researchers in preservice teaching and early in their careers. He encouraged classroom teachers to research as part of their jobs with a focus on their own teaching and students in order to improve the profession instead of trying to meet expectations of the academy. In other words, teachers should conduct their research in their own practice, in their own classrooms, and at their own schools and communities. In this space they are perfectly positioned to make important contributions to improving practice and student learning. He saw a reciprocal relationship between the development of Teachers as Researchers and the development of teacher educators as Researchers, using their prior knowledge as teachers to focus their research on improving what is happening in classrooms. He felt both teachers and teacher educators share the same goals: improved teaching and learning.

We begin to wonder if barriers to developing a researcher identity, for teacher educators or teacher candidates, could be rooted in a lack of identity development and experience as researchers in preservice teacher education programmes and in teacher classroom practice? We build on the work of Butler et al. (2014) and Williams, Ritter and Bullock (2012) that demonstrate that teacher educators need a process or space to reconceptualize themselves and reconstruct new identities as university teacher educators and researchers. As teacher educators, we had a deep desire to help our teacher candidates and ourselves to reconceptualize our identities as teachers and teacher educators as generators of new knowledge. We argue that joining teacher educators with teacher candidates in collaborative inquiries, situated within the context of their own practice (Lieberman \& Miller 2008), can contribute to the development of an inquiry stance about the practice of teaching and simultaneously build both skill and identity as researchers for both teacher educators and teacher candidates. We agree with Hamilton and 
Pinnegar (2015:16) that, 'As members of a new community our participation with each other can help reconsider, adjust, and redesign our identity making'. Figure 1 outlines our process situated within a community of practice for developing both teacher and teacher educator research identity beginning in preservice teacher education.

\section{Teacher as Researcher}

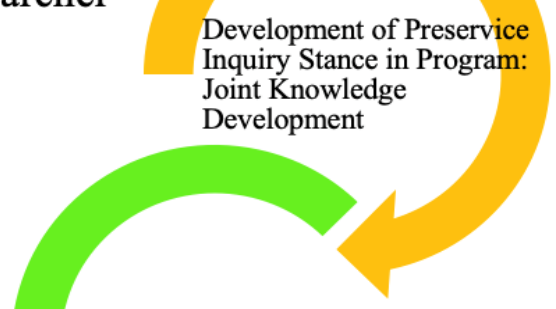

Teacher Educator \& Preservice Teacher in

Collaborative Research: Joint Identity \& Skill

Development

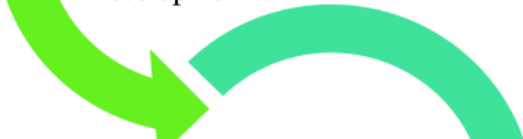

Teacher Educator as Researcher

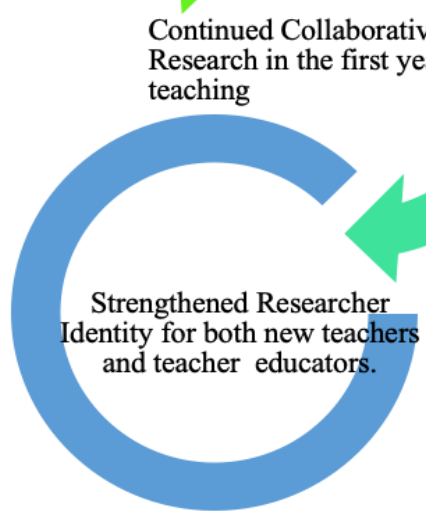

Figure 1. Joint development of teacher and teacher educator researcher identity 


\section{It begins with Inquiry Stance}

Cochran-Smith and Lytle (2001) explain that taking an inquiry stance is a professional positioning towards knowledge and practice that is active, not passive. Additionally, inquiry stance has been connected to the development of a more empowered professional identity (Snow et al. 2018; Wolkenhauer $\&$ Hooser 2017). We join with Fenstermacher (1978) in pushing back against indoctrinating teacher candidates to simply behave in prescribed ways, but instead to provide teacher candidates with opportunities to think critically and reason soundly about their teaching. Inquiry stance as a mindset opens the door for developing researcher identity.

Empowering teacher candidates to question teacher practices through research may reconstruct their own understandings of what teachers are and what teachers do. We believe that through collaborative participation in a community of research practice, teacher educators have an opportunity to model inquiry stance in action and teach the research skills and processes necessary to carry out inquiries to teacher candidates. Within this research community, the teacher educators take on the role of 'research facilitator', helping to guide the collaboration process. They have an opportunity to try on the role of facilitator, thus reconceptualizing their own research identity.

Over the past three years, we have been cultivating the capacity for rigorous research opportunities within our undergraduate population. These undergraduate teacher candidates are enrolled in a four-year teacher preparation programme that is committed to the development of an inquiry stance towards teaching (Carter et al. 2019), but has no direct courses or electives in research methods. In order to unravel the complex weavings of learning/ teaching that can come out of participation in undergraduate research, as Butler et al. suggest (2014), we joined together as a community of practice (Lave \& Wenger 1991). We engaged in a collaborative self-study (Kirk \& Lipscombe 2019; O’Dwyer, Bowles \& Chróinin 2019; Bullock \& Ritter 2011; Hamilton 2009) to examine the question: How do our collaborative experiences within an undergraduate research community inform our identities as teacher educator and teacher candidate researchers?

\section{Theoretical Frameworks and Literature 4.1 'Teacher as Researcher' Identity Development}

Identity development is complex and there are a variety of elements which 
include the combination and interaction between personal and professional identities (Wink et al. 2008; Beauchamp \& Thomas 2009). Wenger (1998) describes identity as the negotiated experience of self, which involves community membership and has a learning trajectory. Wenger's description of negotiating identity contends that this is not something that happens in isolation, but in a community with the support of others. Dinkelman (2011) documents that developing identity as a teacher and as a teacher educator is difficult, as there is little support or attention to identity development as teacher educators transition from classrooms to higher education. He goes on to document the difficulty of developing teacher educator identity as a researcher pointing out that the teacher educator's main work is practice focused. This central focus on teaching professional practice can create a chasm between ideals of being a classroom teacher and a teacher educator researcher. It requires the power of both the individual and the community to build a bridge across this conceptual chasm.

Unfortunately, in order to gain credibility as a researcher, some teacher educators try to create a distance between their former self as teacher and their current self as a teacher educator researcher, and in the process widen the chasm. Murphy, McGlynn-Stewart and Ghafouri (2014:245) have found that teacher educators do not always 'see how our previous and current roles in education could both influence and support our endeavours as writers of research in the field of teacher education'. Instead, teacher educators may feel the need to 'filter out teacher/consultant/instructor lenses' in an effort to increase the validity and rigor of their research. This is a problem that begins in teacher education programmes, which pay little attention to the identity development of teacher candidates as researchers.

Beauchamp and Thomas (2009:185) warn teacher education programmes not to ignore the development of teacher identity. While it may be unintentional, the exploration of one's identity within teacher preparation programmes may not always be an explicit part of the plan for teacher development. Teacher identity, however, is complex. Not only do teacher candidates need to be supported in remaking the identity of a professional teacher, but in order to begin to uncover their own authority as knowledgemakers, teacher education programmes will need to support teacher candidates in their development of teacher as researcher through involvement in undergraduate research.

Undergraduates in teacher education programmes are not always 
exposed to research methodology courses, and may carry out tasks of research without owning the process with potential to be agents of change (Price \& Valli 2005). Without this experience, teacher candidates may not have the tools for conducting valid research or see the value research holds for transforming their own practice in the future. Teacher education programmes may not always emphasize the long-term benefits for the teacher as a developing researcher (Slobodzian \& Pancsofar 2014). The complexities inherent in preparing teachers to engage successfully in the work of teaching, while simultaneously attending to rigorous accreditation standards, narrows what can be taught. Hamilton and Pinnegar (2015:XXIV) highlight that teacher education curriculum is an international problem. What gets taught and what is excluded due to time constraints is a tension felt by all. 'Across countries that task is the same - prepare teachers in knowledge of and skills for teaching and to orient them to take up the needed dispositions to be strong teachers'. We believe that engagement in undergraduate research can help teacher candidates to reinvent their conceptions of what a 'teacher is and does' and therefore could have a significant impact on identity development and practice.

\section{Socially Cohesive Communities of Practice}

Studying our own practice in community with our undergraduate teacher candidates provided us an opportunity to learn from all our collective experiences while facilitating the research process, methods, and skills with novice researchers. Just as teacher candidates 'are simultaneously teachers and learners - growing into their identities as professional educators - so are teacher educators' (Snow et al. 2019:255). We see our community as a 'social container that helps foster mutual development and support our aspiring practice intentions' (McAlister 2016:3).

The learning that occurs within a community of practice is often very individualized and realistic. Engaging in research at this level, within an undergraduate programme, allows for change within one's learning and 'follows that learners' perspectives on work will be different, and their comprehension of the practice will change across the process of learning' (Lave \& Wenger 1991:69). Legitimate participation in practice is defined as having access and opportunities to be involved in the community at a holistic level, rather than just one aspect of the activities or processes. In our process, 
all members of this community worked collaboratively and were legitimated participants in all aspects of our research, from conceptualization of the study through the writing process.

Socially cohesive communities of practice hold much promise for the concurrent development of research skill and identity. Wenger (2004) has found that a community of practice has the potential to play a critical role in the development of research, as it has social structures that focus on knowledge and explicitly enable the management of knowledge to be placed in the hands of practitioners. Parent, Kansky, and Lehr (2016:16) tout the ability of communities of practice to create spaces to break down hierarchical structures present in universities that can foster 'inclusivity-oriented undergraduate research mentorship training'. Jones (2010) has found that university-based communities of practice are powerful settings for parallel development of research expertise and pedagogical knowledge. We agree with these researchers and believe that transformational and reciprocal growth flourishes when unusual relationships are formed by transgressing /blurring oppressive/imagined institutional boundaries/ binaries.

\section{Undergraduate Research}

Undergraduate research provides multiple layers of value to institutions of higher education. In a thorough literature analysis identifying the relative frequency of reported benefits of the undergraduate research experience, Seymour et al. (2004) found these - and others - to be the most common: increased student interest in the discipline; increased persistence; enhanced career preparation, including greater readiness for research and professional careers and professional socialization; clarification, confirmation, interest in, or choice of a career path; and increased skills, including working collaboratively, communication, and leadership. These results provide a worthy incentive to consider both faculty and student involvement in undergraduate research because of the positive implications of these benefits on any developing professional.

It is well documented that engagement in undergraduate research provides benefits in student cognitive growth (Seymour et al. 2004) and student retention (Gregerman et al. 1998). However, there exists an inconsistency amongst scholars on the worthiness of faculty mentoring and scholarship in the undergraduate research experience (Rogers 1995). These per- 
Sherry Dismuke et al.

ceived realities about the worthiness of faculty involvement in undergraduate research implored us to explore the benefits of the undergraduate research experience empirically in connection to the reconceptualization of teacher candidate and teacher educator identity.

\section{Methodology: Phenomenological Collaborative Self-Study}

The study takes place at a four-year university, teacher education programme in the north-western United States that provides opportunities for inquiry and critical reflection throughout the programme (Carter et al. 2019; Snow et al. 2019). To examine our own experiences in developing as teacher educators and undergraduate researchers, three university teacher educators joined with two undergraduate teacher candidates to participate in a phenomenological collaborative self-study (Kirk \& Lipscombe 2019; O’Dwyer, Bowles \& Chróinin 2019; Bullock \& Ritter 2011; Hamilton 2009). Collaborative selfstudy is well connected to our research purpose, as it enables critical reflection and provides a conduit for layers of critical friendships to examine self-reflections that surface (O'Dwyer et al. 2019). Collaborative research and self-study in which students engage in research with more experienced mentors have been shown by Kirk and Lipscombe (2019) to be a research methodology that has the potential to develop research capabilities, while at the same time developing researcher identities. Our collaborative self-study took place through the generation of data over time as we built trust through critical friendships (Hamilton 2009).

Stolle et al. (2019:23) define a critical friendship as 'a friendly (meaningful, trustful) relation so that you, if needed, can give a hard critique'. Aligning with Jones (2010), we believe that constructive criticism by peers provides opportunities to reflect. In creating a critical community of practice, we 'developed shared understandings of the complexities of teacher education and collaboration as we engaged in reflective discussion focused on relating our research and collaboration to our practice' (Murphy et al. 2014:240). We sought to establish three characteristics of successful critical friendships as identified by Stolle et al. (2019): vulnerability, reflection and scepticism. In this space we were able to use our critical friendship to challenge and debate each other's accounts of our personal narratives, by first challenging each other's stories with critical questions 
with a trusted peer, building towards vulnerability within the whole group (Hamilton 2009; Hernandez et al. 2010:7).

\subsection{Participants}

The participants are two Clinical Associate Professors; James with ten years of experience in higher education and Sara with eight years' experience; and one Clinical Assistant Professor, Lydia, with seven years' experience in higher education. We all moved into higher education after successful careers as classroom teachers and one as a principal. Our identities as educators were first formed as public-school teachers, this at times causes conflicts with our roles in higher education (Dana \& Yendol-Hoppey 2009). We all teach education courses, supervise teacher candidates in schools, and two of us have taken on administrative roles. James began working underground with undergraduate researchers outside his workload in 20172018. Lydia and Sara were inspired to join him in 2018-2019.

Sara has a $10 \%$ research load as part of her contract. She has been fully supported and mentored in research by two full professors and publishes work well above her $10 \%$ contracted requirement. However, she still struggles to gain respect from many of her tenure-track peers as a researcher. James and Lydia have no contracted research work. They have participated in collaborative research with tenure-track mentors, but conduct research and publish outside of their assigned contract workload and annual evaluations.

James and Lydia have been named as an Aligning Stakeholders and Structures to Enable Research Transformation (ASSERT) Fellow. This is a cohort faculty development programme for faculty from all ranks and various academic units towards transformational research. James and Lydia applied for an Internal Seed Grant through their College to fund their work with undergraduate researchers. The project was denied, with indications that the research proposed would likely not bring funding to the University and/or be sustainable in a long-term model.

We collaborated with two undergraduate researchers (UGRs), Jadelyn and Meghan, who voluntarily chose to participate in undergraduate research outside the requirements of their degree programmes and work requirements. Jadelyn and Meghan have been participating in undergraduate research since their freshman year. They have already presented at two 
Sherry Dismuke et al.

national teacher education conferences, have taken up leadership roles in the Teacher Education Ambassadors - a student organization at the university that focuses on service and building community as teacher candidates - and worked alongside James and Lydia to create our newly formed undergraduate research group the Undergraduate Collaborative for Research in Equity and Access in Teaching (UCREATe).

\subsection{Data Sources \& Analysis}

To combat any surface tensions that could have emerged in our hierarchical structures, we began within the safety of individual memory work (Samaras 2011). We wrote narratives in a journal of our past experiences with research and our individual journeys that led us into our current positions. These narrative journal entries continued through the project to capture our individual experiences of a research project that spanned the 2018-2019 schoolyear and into the Fall of 2019.

In addition to our personal narratives, three rounds of mirrored survey prompts were created to address our research questions and completed by all participants. Each participant was free to tell their own narrative in their own style. The survey prompts had mirrored or married questions that were tailored for undergraduates and faculty. For example, clinical faculty members wrote to the prompt: What does it mean to be a clinical faculty member? While teacher candidates responded to the prompt: What does it mean to be a teacher?

In order to establish the trust required for critical friend conversations (Hamilton 2009), we created a Critical Friend Group (CFG). We first addressed our hierarchical roles as a barrier by first having the clinical faculty participants read and respond to one another's journals and prompt responses, and having the UGRs respond to one another. In these groupings we had already established trusting relationships and there were no hierarchical structures in play. We read our peers' journals and prompt responses looking for dissonance in their narratives. After reading the responses of our peers, we each prepared two critical and probing questions for each of our group members to surface or probe places of disagreement in their stories. We met in our non-hierarchical groups for round one of a CFG and recorded our responses to the probing questions posed by our peers.

Figure 2 outlines the study design and data collection process. 


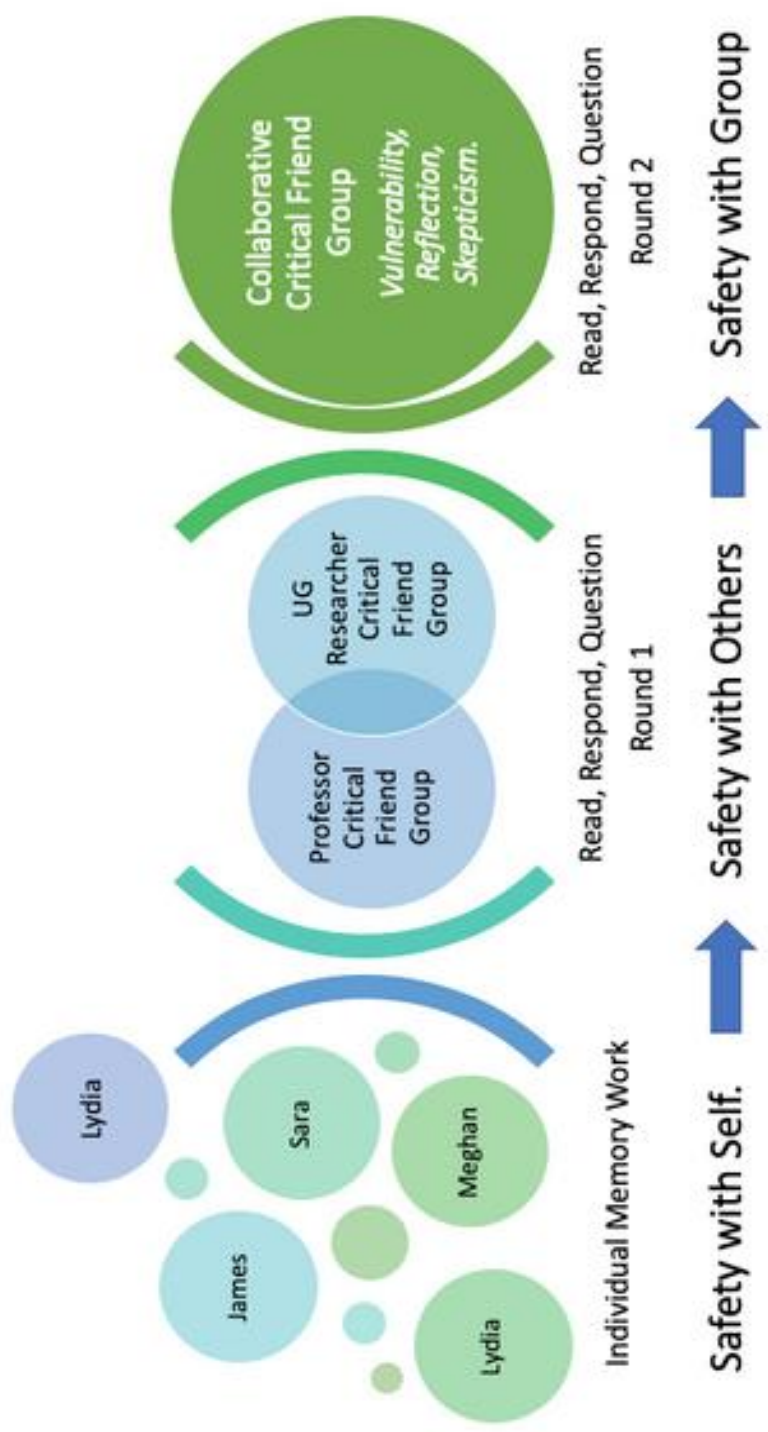

Figure 2. Building trust in a critical friend group towards developing; vulnerability, reflection, and skepticism 
After practising our process with those we were most comfortable with, for round two of our CFG conversations we worked across groups. Faculty read UGR journals and prompts, and UGR read faculty journals and prompts. We prepared questions across groups and met for a second CFG conversation. This same process was repeated in 2019 - 2020. Data sources included researcher journals, written responses to prompts, meeting notes, and transcriptions of CFG conversations.

Data analysis began with each participant reading their own data set and creating memos. Next, they were assigned a member of their heterogeneous group to read their partner's data sources to look for codes that emerged. Each group coded their responses and met in heterogeneous groups to discuss emerging codes. For our second focus group everyone met together to discuss and probe all data sets. We identified overlapping codes across our data sets and then continued our cyclical coding for all data sources (Saldaña 2016). Last, we met to chunk our overlapping codes into themes (Saldaña 2016). From these themes we derived the following findings.

\section{Findings}

Analysis across data sources revealed an impact on our identity development and actions as teacher educators and teacher candidates. Three main findings emerged: Shedding Old Frames and Discovery of New Identities, Connecting Identity and Purpose, and Finding Curious Others. Joint reflection of these findings in our CFGs led us to identify a more sustainable model for supporting undergraduate research. Below, we discuss our understanding of the shifts we experienced in our identities as educators, and then provide connections to our data. Lastly, we describe the action we took toward sustainability by creating a more inclusive community of practice available to all emerging undergraduate researchers and faculty.

\subsection{Shedding Old Frames and Discovering New Identities}

Data identified overall changes in our identities as researchers. Early data revealed that participant identities were steeped in our institutional positioning as clinical teacher educators and preservice teachers, both of which were not expected to produce research or generate new knowledge. Participation in this experience changed the way we conceptualized our roles and identities 
as legitimate researchers. Similarly, before this study, the UGRs saw teaching and researching as very separate, and originally struggled to see how their outside, voluntary research work directly connected to their courses in the teacher preparation programme. The UGRs reported experiencing a disconnect between learning to be a researcher and learning to be a teacher since the two were not connected in the programme and research work was not assigned value or credit within the teacher preparation programme.

\subsection{Shifts in Identity for Teacher Educators}

Each teacher educator reported shifts, or a gradual remaking of our individual identities. Data from focus groups, narratives and journal entries documented changes over time that were facilitated by our participation in our group. In early narratives and interactions, clinical faculty reported feeling like imposters as research facilitators, despite having doctorates and each having published research. Lydia's journey illustrates the shift in identity the clinical teacher educators experienced.

Lydia admitted, "I'm not a researcher", I wrote that ... Do I know enough'? (FCFG R1:4). As James and Sara probed Lydia further and confronted her with the research she had conducted she said, 'I' $m$ still trying to find my place, I think, in this world of higher [ed]. A place where I feel like I fully respect myself and [am] respected by others'. James responded back, 'I know and I had imposter syndrome, too' (FCFG R1). As the clinical faculty members read each other's data and met, we discovered a common denominator in our identity development: We all had always used research to solve problems of practice or defend our teaching practices. However, like Murphy et al. (2014:245) found, we were hesitant to 'claim our burgeoning identities as writers of educational research'.

Our CFG conversations had us confront our own conceptions about what counts as research at the university. We had to grapple with the frames others have put on what is accepted as 'real research'. Lydia wrote in her narrative, 'it seems that the particular research we are attempting to conduct and be made known is not seen as reputable or respectable in the research community' (LJ R1:4). When challenged by James in a critical friend group, Lydia went on to explore the dissonance of her narratives when she talks about the research she had conducted in the past against the backdrop of not feeling like a researcher. She continued, 
Sherry Dismuke et al.

Until I begin producing what others would consider 'truer' forms of research, either in type of research or in what can bring in the most tangible reward for the University, I would assume that my advising of undergraduate researchers would continue to be voluntary and unappreciated (LJ R3:4).

We recognized a need to build on the research skills we had developed to feel more competent. Books were ordered for the group and all participants read more about the methodologies we were engaged in. Lydia wrote in response to prompt 1 ,

I must 'know my stuff' or they will be at a loss for a good leader. This is often an intimidating realization, but something that also encourages me to eliminate the opportunity for complacency in who I am as a professional (LJ 13:6 Prompt 1).

Our research community became a place for us to push ourselves to grow into the researchers we felt we were not.

I feel I would be amiss to ignore the potentiality this type of involvement would have not only on the undergraduate students, but on my growth as a professional teacher educator (LJ 30:6 Prompt 2).

James was able to articulate the reciprocal nature of our growth in his narrative,

It has been richly rewarding, professionally, in that I am learning and growing alongside the students (AJ Prompt 1).

However, there was still self-doubt.

Within our community of practice the faculty were able to voice their feelings of self-doubt and memories of times they had been disrespected as researchers. What emerged after that was a sense of renewed focus and purpose. James got us back on track when he pushed Lydia's desire for recognition, 'We're not doing it to be valued, right? We're doing 
it because we care about it. We're curious' (FCFG R1). It was only when we named and owned our own curiosity and self-motivation for conducting research when we realized that research was a part of our individual identities. Sara realized,

I'm so curious about so many things that I just can't not do it. I've tried to lay that down and say, just focus over here. And then another idea comes up that I'm super curious about and I'm like, oh, I want it, I want that project because I want to see. It's just my nature (FCFG R1:5).

James articulated what we were all feeling when he said, 'We research because it is our nature to want to know'.

Faculty confidence in our role as researchers and research facilitators grew as we witnessed the growth in the teacher candidates. Our ability to guide the research process, take on responsibility for critiquing methodology, and engaging in critical conversations was building our confidence as researchers. When we witnessed the growth in our candidates, there was a sense that perhaps we were not the imposters we believed ourselves to be. It motivated us to continue to learn and grow into our roles. Lydia wrote in her journal,

The major external influencer for working with undergraduate researchers is the researchers themselves. I have been able to witness a shift in their professional identity, their demonstrated dispositions, and their depth of discussion on topics of education. When comparing these undergraduate researchers to their peers in the programme who have not engaged in research, there is a noticeable difference in their curiosity, their thirst for knowledge, and their professional discourse (LJ RI:3).

\subsection{Shifts in Identity for Undergraduate Researchers}

Discussion in our CFGs shifted the way the teacher candidates viewed themselves. Jadelyn said,

I got involved because I wanted to learn more and be better prepar- 
Sherry Dismuke et al.

ed as a teacher, but then I just feel like there's so much more to the (teaching) profession. And Ifeel like doing research has allowed me to kind of start to see the broader scope of what the profession entails (CCFG 1:23).

Meghan added,

I feel like it's changed my professional goals a lot. People are like, 'Oh, that's so cute. Like, you're going to be a teacher.' Everyone says that, but. . . it's so much more than that (CCFG 1:24).

The UGRs' definition of a teacher shifted to include 'researcher' (UGCFG 1:5). Jadelyn explained this shift in a later journal entry,

I have always been curious, but by doing research I have learned ways to actually delve deeper into specific topics and I am learning how to develop specific and measurable questions and methodically work towards an 'answer' or a better understanding. This mindset will translate into my classroom someday with student assessments and working towards solving problems that my students are facing (JJ R1:5).

Participation in our community of researchers has given all of us a collective purpose to stretch ourselves and develop skills that have helped us shed the limitations of institutional roles and reconceptualized our identity around this energizing work as teacher educators and teacher candidate researchers.

\section{Connecting Identity and Purpose: The Moral Imperative}

Palmer (1998) talks about identity and integrity being at the heart of teachers' work. Reading our individual narratives and interactions reinforced that purpose, to engage in research regardless of compensation or recognition. Data across sources pointed to the reasons for 'why' all participants wanted to develop themselves as researchers. One reason that was shared by both undergraduate and faculty participants was the 'Moral Imperative' of teacher research. Sara said, 'It [research] is at the heart of teaching, it is what good teachers do' (SJ R1:2) and Lydia said, 
My hopes for this type of reform raise every time I have a conversation with one of our undergraduate researchers about how their project is impacting their practices as a future teacher. The evidence exuded in these undergraduate researchers is enough to inspire me to continue forward toward change (LJ R1:4).

The UGRs begin expanding the purpose and role of teaching. Jadelyn said,

This research that we're doing is making us realize that we need to do [research] as teachers and what we think other future teachers and current teachers should be doing (JJ R1:6).

Our identity as clinical faculty and UG educators was bound up in problematizing teacher practice, and we talked further about the work having more value and meaning to us personally than other work for which we are responsible. James framed his work with UGRs, saying, 'This work has to do with professional identity and self-advocacy' (CCFG: 20). In his narrative, he foreshadowed his advocacy for this work, saying,

I am hell-bent on changing the way schooling, teaching, and teacher education are done and I think re-creating the role of 'teacher' is integral to that (AJ R1).

James is determined to provide an undergraduate research experience to his teacher candidates even if it means doing work he is not paid to do. 'I think that 'teacher as researcher' is a key to all of it, and to changing what American society looks like today' (AJ R1).

Witnessing James's experience in the process, Lydia is willing to stretch into the role and assume the identify a of Faculty Research Mentor, saying,

Providing this opportunity - an opportunity to walk through the typically-unopened door into the world of research - for our undergraduate students provides them with a mind-shifting opportunity as a person and as a future professional (LJ R1 19:6).

Her identity as a researcher was impacting her practice as a teacher 
Sherry Dismuke et al.

educator. She wrote in her journal about connecting her intersecting roles in research with her purpose as a teacher educator,

Our sole purpose in education should be serving students, and in doing so to be ever-present in our work and never stagnant about our work. This takes curiosity, willingness, and discovery on the part of the teacher (LJ 30:7:4).

After analysing this theme, we found that we all shared a strong conviction that teachers and teacher educators have an obligation to engage in research in order to improve practice and student learning. This shared belief motivated us to continue to develop into the role of researcher. Digging deeper into our group's holistic narrative, we uncovered another more intrinsically motivating purpose.

\section{Finding Curious Others and Losing our Balance}

Our desire to engage in a community of 'curious others' emerged as a second purpose for engaging in research. Transcripts from the CFG's contained multiple conversations about what Albert Einstein called The Holy Curiosity of Inquiry (Schilpp 1949). Both faculty researchers spoke about the value of 'finding curious others' and doing this work together in a community. However, this desire for the synergy of the community resulted in a loss of work life balance. James reflected on his department faculty meetings and compared them with all of us carving out time to meet together in our community, often very early in the morning before campus life started for the day:

Am I going to whatever Friday afternoon meeting...Or am I choosing to sit around with a group of young, energetic students who want to change the world? Are you kidding me? Totally nuts. No choice (FCFG R1).

Coming into the work with self-doubt, the community provided a safe space for all to grow our skills together. The community also held members accountable, and remained stable and supportive when participants sought balance in their lives. Jadelyn said, 
The biggest external influence on me continuing to do research is the team of peers and advisors that I work with. On my own I have all the passion and curiosity, but without a team I would probably never actually get any work done (JJ 30:6:4).

She went on to say,

I feel very accountable to the group so that I know that I need to be ready. And like you're all counting on me. And so that's why I feel like I'm able to continue (UGCFG R1 8:19).

Each participant felt the burden of time, but the work brought us all joy outside the demands of our roles. Sara took on a new administrative position in addition to her teaching and supervision. Despite being overwhelmed with her new role, she found herself working through the weekend to be able to continue her work with curious others.

I have said no to many extracurricular projects this year, but for some reason I can't let undergraduate research go. Honestly, some days I am barely breathing. However, when I sit down with Jadelyn and Meghan, I am somehow in a place of safety. Our creative juices start to flow and I feel in flow. There is a real duality, it creates more work hours, here I am working on the weekend to get this writing done; on the flip side, it carves out a space where Ifeel some joy in my work (FCFG R1).

When unpacking this theme, we noticed that the fire that fuelled our curiosity often led to a loss of balance. Examples of finding joy, synergy, and passion were almost always intertwined with accounts of poor self-care or not fulfilling other personal or work/school responsibilities. Conversations in CFG questioned if the underground nature of our work could continue. James talked about time as a barrier for us as faculty in his journal,

The biggest barrier to working with undergraduate researchers is time - time in conflict when scheduling with one another; time outside of documented workload; juggling time with my priority of being with my family; time to dedicate specific focus to this work; 
Sherry Dismuke et al.

and requesting time for undergraduate researchers to volunteer outside of their full-time student, working, and personal schedules. This time to be the barrier that all other barriers result in (AJ R1:2).

During CFGs (UGCFG R2) Meghan and Jadelyn admitted to staying up all night in order to fit in their research agendas. Meghan said,

For me, I usually let taking care of myself give. So, like, I will just stay up, like all night long or whatever, so that I can get my school stuff and research stuff done. So that's a big thing that I sacrifice ... my own kind of well-being.

Meghan was not alone. Jadelyn admitted,

My biggest barrier to doing research is probably my life ... I try to be involved in a lot and do well... that does not leave much time for sleep or mental health, which can be very challenging (JJ R2 19:6).

When pressed in the CFG, Jadelyn admitted 'I feel like I'm going to disappoint this research team' (UGCFG R2 19:4:3). Jadelyn and Meghan wanted to find a way to invite more of their peers into this work, but were hesitant. 'This is so much work, and we feel like we're dying all the time, then they're not going to want to do it. Like, that's not a good selling point' (CFG 19:4:9).

When confronted with Jadelyn and Megan's data, James, Lydia and Sara were very conflicted. They worried that they were facilitating a disposetion of over-achievement which the three faculty members openly confessed to having. James pushed on Lydia and Sara's sensibilities as parents,

Do you tell any of your children that? Or would you tell them to find something that you can do well, that serves others, but also maintains a level of your self-care and right, self-worth? (FCFG R1:5).

While the analysis detailed the importance of community as a motivating factor for engaging in research, it also revealed that our model of engagement was not sustainable. After reviewing these findings, the com- 
munity decided things would have to change to make the work we loved sustainable for both current and future members of our research community.

\section{Sustainability: The Undergraduate Collaborative for Research in Equity and Access in Teaching}

At the end of round one of the CFG data analysis that took place from 20182019, the research community realized that as important as this work was to us, it was unsustainable. Sara, Lydia, and James begin to wonder if we were doing more harm than good to our UGRs when we read their accounts of 'hitting the wall'. Initial findings inspired community action. James and Lydia, in collaboration with Meghan and Jadelyn, decided it was time to bring the work they were engaged in above ground and scale up the opportunity for more undergraduates. Together they established the Undergraduate Collaborative for Research in Equity and Access in Teaching (UCREATe). This research collaborative was created as a space where undergraduate researchers could partner with faculty to pursue inquires that explore inequities in teaching practices and systems, and improve access to quality teaching and curriculum for $\mathrm{p}-12$ students.

Confident as researcher facilitators, James and Lydia began involving tenure-track faculty into the projects. They recruited a team of faculty members, both tenure-track and clinical-track, that were willing to serve as undergraduate advisors, with a twist. Instead of the UGRs serving as 'research assistants' to existing faculty projects, the faculty supported the candidates in their own self-selected inquiries. In late journal entries, Lydia and James' new confidence shows when they explore their reasons for starting UCREATe. Lydia said,

I see it providing vital opportunities for me to continue adding to my expertise, for me to serve my teacher candidates, and for me to initiate excitement amongst my colleagues about the benefits and necessity of undergraduate research in our teacher preparation program (LJ R4).

James shared,

Doing this particular work reinforces what I love about the possi- 
Sherry Dismuke et al.

bilities of undergraduate education and teacher preparation and it has enabled me to make more and deeper professional connections and build important relationships at my university and within the community (AJ R4).

UCREATe provides a space where undergraduate students can develop into professionals who believe research is integral to their job and understand how to engage in meaningful research that challenges practices and develops solutions that supports p-12 learners. For example, as UCREATe leading faculty, James and Lydia initiate conversations with interested students that lead toward student-directed and faculty-supported research projects. As projects develop, students are provided opportunities to connect with tenure-track or clinical-track expert faculty in the topics being examined and/or the methodology of the study in order to support the students towards structured, focused, and purposeful research practices. The membership of other university faculty such as Library Liaisons and The Writing Center demonstrate the meaningful levels of support that was integrated into the UCREATe model - as Near Peers (Lave \& Wenger 1991). Near Peers, like Meghan and Jadelyn, are other UGRs who have previously and/or are currently experiencing the research process as undergraduate students, and provide a first-hand perspective on the process for their peers. Jadelyn explained her role as Near Peer in her Journal,

... I also am very excited at the possibility of contributing to the profession of teaching as a whole ... I feel like I am a part of something much bigger than myself, and that my research could potentially impact the way future students learn and future teachers practice (JJ R5).

The support of the Near Peers in the UCREATe model creates a sustainable vision for undergraduate research at the university, where developing UGRs are encouraging, sharing, and enacting the curiosity towards becoming a teacher.

\section{Discussion}

This study recognizes that narratives told by self, not others, is a powerful 
tool for developing identity. However, summoning the gaze of critical others was an important dimension for learning, and ongoing shifts of change and redefinition. In alignment with Hamilton and Pinnegar (2015) and Macintyre (2001), coherence of our shifting identities was only achieved when the telling of our own narratives and our new experiences as researchers, was challenged by critical friends. This dissonances between the narratives and experiences in the research community enabled each participant to identify and grapple with the contradictions in our stories. This wrestling with self, resulted in a new framing or retelling of self and professional identity (Macintyre 2001; Hernandez et al. 2010).

One powerful reframing for us all was the ways in which the two teacher candidates reconceptualized the role of teacher as inclusive of researcher. Prior to the study they both struggled to see any connection between their research selves and their teacher education courses or future roles and teachers. After the study they saw research as woven into the fabric of teaching. A parallel reframing occurred for teacher educators as well.

\section{In the end ...}

In the end, involvement in undergraduate research has had a definite impact on all participants' identities. It has expanded notions of what it means to be a teacher and what it means to be a teacher educator. Engagement in this work was supported and legitimized by our involvement with each other in a trusting, alternate community. Collective inquiry as safe, respectful spaces for both teacher educators and undergraduate candidates to co-construct researcher identities brought undergraduate communities out of the shadows to create a sustainable community of practice around research. The collaborative, cohesive nature informing research communities highlights the influence that joint research of teacher practice can have on developing legitimate generators of knowledge.

\section{References}

Beauchamp, C. \& L. Thomas 2009. Understanding Teacher Identity: An Overview of Issues in the Literature and Implications for Teacher Education. Cambridge Journal of Education 39,2: 175 - 89. Available 
Sherry Dismuke et al.

at: https://doi.org/10.1080/03057640902902252

(Accessed on 20 May 2021.)

Bullock, S. \& J. Ritter 2011. Exploring the Transition into Academia through

Collaborative Self-Study. Studying Teacher Education 7,2: 171 - 181.

Available at: https://doi-org.libproxy.

boisestate.edu/10.1080/17425964.2011.591173

(Accessed on 7 January 2021.)

Butler, B.M., E. Burns, C. Frierman, K. Hawthorne, A. Innes \& J.A. Parrott 2014. The Impact of a Pedagogy of Teacher Education Seminar on Educator and Future Teacher Educator Identities. Studying Teacher Education 10,3: 255 - 274. Available at:

https://doi.org/10.1080/17425964.2014.956716

(Accessed on 09 November 2020.)

Carter, H., J.L. Snow, S. DiGrazia \& S. Dismuke 2019. Finding our Place in the Third Space: The Authority of Not Knowing as Becoming. In School - University Partnership Work. School - University Partnerships 12,3: $95-105$.

Cochran-Smith, M. \& S.L. Lytle 2001. Beyond Certainty: Taking an Inquiry Stance on Practice. In Lieberman A. \& L. Miller (eds.): Teachers Caught in the Action: Professional Development that Matters. New York: Teachers College Press.

Dana, N.F. \& D. Yendol-Hoppey 2009. Reflective Educator's Guide to Classroom Research. $2^{\text {nd }}$ Edition. Thousand Oaks, CA: Corwin Press.

Dinkelman, T. 2011. Forming a Teacher Educator Identity: Uncertain Standards, Practice and Relationships. Journal of Education for Teaching 37,3: 309 - 323. Available at:

https://doi.org/10.1080/02607476.2011.588020

(Accessed on 8 March 2017.)

Fenstermacher, G.D. 1978. A Philosophical Consideration of Recent Research on Teacher Effectiveness. Review of Research in Education 6,1. Available at: https://doi.org/10.3102/0091732X006001157

(Accessed on 20 May 2021.)

Gee, J. 2000. Identity as an Analytic Lens for Research in Education. Review of Research in Education 25: 99 - 125. Available at:

http://www.jstor.org/stable/1167322 (Accessed on 7 January 2021.) https://doi.org/10.3102/0091732X025001099

Goodwin, A.L. \& C. Kosnick 2013. Quality Teacher Educators = Quality 
Teachers? Conceptualizing Essential Domains of Knowledge for Those who Teach Teachers. Teacher Development: An International Journal of Teachers' Professional Development 17,3: 334 - 346. Available at: https://doi.org/10.1080/13664530.2013.813766

(Accessed on 10 December 2020.)

Gregerman, S.R., J.S. Lerner, W. von Hippel, J. Jonides \& B.A. Nagda 1998. Undergraduate Students - Faculty Research Partnerships Affect Student Retention. Review of Higher Education 22,1: 55 - 72. Available at: https://doi.org/10.1353/rhe.1998.0016

(Accessed on 10 December 2020.)

Hamilton, M.L. 2005. Researcher as Teacher: Lessons Modeled by a WellRemembered Scholar. Studying Teacher Education 1,1: 85 - 102. Available at: https://doi.org/10.1080/17425960500040122 (Accessed on 10 December 2020.)

Hamilton, M.L. 2009. The Somehow of Teaching: Small Groups, Collaboration, and the Self-study of Teacher Education Practices. In Craig, C.J. \& L.F. Deretchin (eds.): Teacher Learning in Small-Groups. Teacher Education Yearbook XVII. Lanham, Maryland: Rowman \& Littlefield Education.

Hamilton, M.L. \& S. Pinnegar 2015. Knowing, Becoming, Doing as Teacher Educators: Identity, Intimate Scholarship, Inquiry. UK: Emerald Publish Co. https://doi.org/10.1108/S1479-368720140000026035

Hernandez, F., J.M. Sancho, A. Creus \& A. Montane 2010. Becoming University Scholars: Inside Professional Autoethnographies. Journal of Research Practice 6,1. Available at:

https://files.eric.ed.gov/fulltext/EJ902372.pdf

(Accessed on 09 November 2020.)

Jones, E. 2010. A Professional Practice Portfolio for Quality Learning. Higher Education Quarterly 64,3:, 292 - 312. Available at: https://doi.org/10.1111/j.1468-2273.2010.00458.x

(Accessed on 20 May 2021.)

Kirk, M. \& K. Lipscombe 2019. When a Postgraduate Student Becomes a Novice Researcher and a Supervisor Becomes a Mentor: A Journey of Research Identity Development. Studying Teacher Education 15,2: 179 - 197. Available at: https://doi.org/10.1016/j.tate.2004.12.006

(Accessed on 20 May 2021.)

Lave, J. \& E. Wenger 1991. Situated Learning: Legitimate Peripheral 
Sherry Dismuke et al.

Participation. Cambridge England: Cambridge University Press. https://doi.org/10.1017/CBO9780511815355

Lieberman, A. \& L. Miller 2008. Teachers in Professional Learning Communities: Improving Teaching and Learning. New York, NY: Teachers College Press.

Luna, C., M.J. Botelho, D. Fontaine, K. French, K. Iverson \& N. Matos 2004. Making the Road by Walking and Talking: Critical Literacy and/ as Professional Development in a Teacher Inquiry Group. Teacher

Education Quarterly 31: 67 - 80. Available at:

https://www.jstor.org/stable/23478416

(Accessed on 20 May 2021.)

Macintyre A. 2001. The Virtues the Humanity of Human Life, and the Concept of a Tradition. In Hinchman, L.P. \& S.K. Hinchman (eds): Memory, Identity, Community: The Idea of Narrative in the Human Sciences. Albany New York: SUNY Press.

Martin, S. J.L. Snow \& C. Torrez 2011. Navigating the Terrain of Third Space: Tensions with/ in Relationships in School - University Partnerships. Journal of Teacher Education 62,3: 299 - 311. Available at: https://doi.org/10.1177/0022487110396096

(Accessed on 09 November 2020.)

McAlister, M. 2016. The Creative Nature of Communities of Practice. Transformative Dialogues: Teaching \& Learning Journal 9,2: 1-7. Available at: https://doi.org/10.22329/celt.v9i0.4425

(Accessed on 29 July 2021.)

Murphy, S., M. McGlynn-Stewart \& F. Ghafouri 2014. Constructing our Identities through a Writing Support Group: Bridging from Doctoral Students to Teacher Educator Researchers. Studying Teacher Education 10, 3: 239 - 254. Available at:

https://doi.org/10.1080/17425964.2014.949656

(Accessed on 09 November 2020.)

Murray, J. \& T. Male 2005. Becoming a Teacher Educator: Evidence from the Field. Teaching and Teacher Education 21,2: 125 - 142. Available at: https://doi.org/10.1016/j.tate.2004.12.006

(Accessed on 10 December 2020.)

Ng, L.L. \& J. Pemberton 2013. Research-based Communities of Practice in UK Higher Education. Studies in Higher Education 38,10: 1522 - 1539. Available at: https://doi.org/10.1080/03075079.2011.642348 
(Accessed on 7 January 2021.)

Northfield, J. 1993. Interpreting Some Different Approaches to Teacher Education. Paper presented at the meeting of the National Association for Research in Science Teaching, Atlanta. ED361301.

Northfield, J. 1994a. Rethinking the Way the Practicum Contributes to Learning to Teach. Paper presented at the meeting of the American Educational Research Association, New Orleans. ED376126.

Northfield, J. 1994b. Researcher as Teacher: Making the Learning Accessible. Paper presented at the meeting of the American Educational Research Association, New Orleans. ED371031.

O’Dwyer, A., R. Bowles \& D.N. Chróinin 2019. Supporting Collaborative Self-Study: An Exploration of Internal and External Critical Friendships. Studying Teacher Education 15,2: 139 -159. Available at: https://doi.org/10.1080/17425964.2019.1600494

(Accessed 20 May 2021.)

Palmer, P.J. 1998. The Courage to Teach: Exploring the Inner Landscape of a Teacher's Life. San Francisco, CA.: Jossey-Bass.

Parent, R.A., N. Kansky \& J. Lehr 2016. Creating Community through Faculty Development to Support Inclusive Undergraduate Research Mentorship. Transformative Dialogues: Teaching \& Learning Journal 9,2: 1 - 20. Available at:

http:///Users/cheryledismuke/Downloads/1041-Article\%20Text-3359-

1-10-20200630\%20(2).pdf

(Accessed 20 May 2021.)

Price, J.N. \& L. Valli 2005. Preservice Teachers Becoming Agents of Change: Pedagogical Implications for Action Research. Journal of Teacher Education 56,57. Available at:

https://doi.org/10.1177/0022487104272097

(Accessed on 10 December 2020.)

Rice, M.F., M. Newberry, E. Whiting, R. Cutri \& S. Pinnegar 2015. Learning from the Experiences of Non-Personhood: A Self-Study of Teacher Educator Identities. Studying Teacher Education 11,1: 16 - 31.

Available at: https://doi.org/10.1080/17425964.2015.1013024

(Accessed on 10 December 2020.)

Rogers, E. 1995. Diffusion of Innovations. $4^{\text {th }}$ Edition. New York: The Free Press.

Saldaña, J. 2016. The Coding Manual for Qualitative Researchers. Los 
Sherry Dismuke et al.

Angeles, CA: Sage.

Samaras A.P. 2011. Self-Study Teacher Research: Improving your Practice through Collaborative Inquiry. Thousand Oaks, CA: SAGE.

Schilpp, P. 1949. Albert Einstein: Philosopher-Scientist: 'Autobiographical Notes'. Evanston.

Seymour, E., A.B. Hunter, S.L. Laursen \& T. DeAntoni 2004. Establishing the Benefits of Research Experiences for Undergraduates in the Sciences: First Findings from a Three-Year Study. Science Education 88,4: 493 - 534. Available at: https://doi.org/10.1002/sce.10131 (Accessed on 7 January 2021.)

Slobodzian, J.T. \& N. Pancsofar 2014. Integrating Undergraduate Research into Teacher Training: Supporting the Transition from Learner to Educator. CUR Quarterly 34: 3. Available at:

https://citeseerx.ist.psu.edu/viewdoc/download?doi=10.1.1.638.2200\& rep=rep1\&type $=$ pdf (Accessed on 10 December 2020.)

Snow, J.L., S. Anderson, C. Cort, S. Dismuke \& A.J. Zenkert 2018. Teacher Leader Identities and Influences as Defined by Liaisons-in-Residence. In Hunzicker, J. (ed.): Teacher Leadership in Professional Development Schools. Bingley, UK: Emerald Publishing.

https://doi.org/10.1108/978-1-78743-403-520181010

Snow, J.L., S. Dismuke, J. Wenner \& S. Hicks 2019. Facing Practice as Teacher Educators: A Self-Study of Program Graduates. In Preparing the Next Generation of Teacher Educators for Clinical Practice. Advances in Teacher Education Book Series.

Stolle, E.P., C. Frambaugh-Kritzer, A. Freese \& A. Persson 2019. Investigating Critical Friendship: Peeling Back the Layers. Studying Teacher Education 15,1: 19 - 30, Available at: https://doi.org/10.1080/17425964.2019.1580010

(Accessed on 10 December 2020.)

Wenger, E. 1998. Communities of Practice. Cambridge: Cambridge University Press.

Wenger, E. 2004. Knowledge Management as a Doughnut: Shaping your Knowledge Strategy through Communities of Practice. Ivey Business Journal 68,3: 1 - 8. Available at:

https://iveybusinessjournal.com/publication/knowledge-managementas-a-doughnut/ (Accessed on 7 January 2021.)

Williams, J., J.K. Ritter \& S.M. Bullock 2012. Understanding the 
Complexity of Becoming a Teacher Educator: Experience, Belonging, and Practice within a Professional Learning Community. Studying Teacher Education 8,3: 245 - 260. Available at:

https://doi.org/10.1080/17425964.2012.719130

(Accessed on 7 January 2021.)

Wink, D.J., J. Ellefson, M. Nishimura, D. Perry, S. Wenzel \& Hwang Choe 2008. Fostering Preservice Teacher Identity in Science through a Student-Selected Project. Feminist Teacher 19,1: 31 - 46. Available at: https://doi-org.libproxy.boisestate.edu/10.1353/ftr.0.0025

(Accessed on 10 December 2020.)

Wolkenhauer, R. \& A. Hooser 2017. 'Inquiry is Confident': How Practitioner Inquiry can Support New Teachers. Journal of Practitioner Research 2,1. Available at:

https://scholarcommons.usf.edu/jpr/vol2/iss 1/5

(Accessed on 7 January 2021.)

https://doi.org/10.5038/2379-9951.2.1.1028

Sherry Dismuke Assistant Dean of Teacher Education, and Clinical Associate Professor College of Education Boise State University Boise, Idaho, U.S.A. cheryledismuke@boisestate.edu

Dr. Lisa Beymer Clinical Assistant Professor

Boise State University Boise, Idaho, U.S.A. LisaBeymer@boisestate.edu

Julianne Mori Elementary Classroom Teacher Boise State University United States of America Boise, Idaho, U.S.A. juliannemori@u.boisestate.edu 
Sherry Dismuke et al.

Claire Oberg Special Education Teacher

Boise State University

United States of America

Boise, Idaho, U.S.A.

claireoberg@u.boisestate.edu

Dr. A.J. Zenkert

Clinical Associate Professor

Boise State University

North-Western United States

ajzenkert@boisestate.edu 